\title{
Antioxidative Substances (Non enzymatic) in Oyster Mushrooms (Pleurotus spp.)
}

\author{
A. Sudha*, S. Srividhya, P. Geetha and M. Vijayakumar \\ Krishi Vigyan Kendra, Tamil Nadu Agricultural University, Sandhiyur, -636203, T.N., India \\ *Corresponding author
}

A B S T R A C T

\begin{tabular}{|l|}
\hline Ke y w o r d s \\
P. eous, P. sajor- \\
caju, P. flabellatus, \\
H. ulmarius, Non- \\
enzymatic \\
antioxidants. \\
\hline Article Info \\
\hline Accepted: \\
14 July 2017 \\
Available Online: \\
10 September 2017
\end{tabular}

Among the oysters, $P$. eous recorded highest levels of non-enzymatic antioxidative substances. Total glutathione content was significantly very high in $P$. eous, followed by $P$. sajor-caju, $P$. flabellatus and $H$. ulmarius. High level of total phenols, flavanoids, lycopene total carotenoid and vitamin A were recorded in $P$. eous. This was followed by $P$. sajor-caju, $P$. flabellatus and $H$. ulmarius. There was no significant difference in vitamin $\mathrm{C}$ content among the oyster mushrooms.

\section{Introduction}

Mushrooms possess high contents of qualitative protein, crude fibre, minerals and vitamins. Apart from their nutritional potentials, mushrooms are also sources of physiologically beneficial bioactive substances that promote good health. They produce a wide range of secondary metabolites with high therapeutic value. Health promoting properties, e.g. antioxidant, antimicrobial, anticancer, cholesterol lowering and immunostimulatory effects, have been reported for some species of mushrooms. Both fruiting bodies and the mycelium contain compounds with wide ranging antioxidant and antimicrobial activities. Protein rich (Pleurotus spp.) delicious food will help to overcome protein deficiency in the diet of Indian population (Madhusudhanan and Chandra Mohan, 2000). Malnutrition is one of the major health problems in developing countries. Cereal based Indian diet suffers from inadequate protein content. Oyster mushrooms are therefore recognized as non-conventional source of protein, which can bridge the protein gap in the Indian diet. Mushrooms are essential supplements to the cereal diet (Vijaya Khader et al., 1999). The nutritional value of mushroom is rated as one in between meat and vegetables. Oyster mushrooms are rich in amino acids, vitamin, protein, minerals and fiber but low in fat. It is an ideal food for patients suffering from heart ailments, diabetic and ulcers (Mohan and Subash 
Chandra Bose, 1999). They are reported to possess antigastric ulcer activities, reduced the rate of nephron deterioration which might extend the life span of chronic renal failure patient and controls constipation due to high fiber content (Anon, 2000).

Besides nutritive value oyster mushrooms have immense potential as medicines too. In recent years, mushrooms have been exploited for their antioxidative potentials (Ajith and Janardhanan, 2001; Murcia et al., 2002 and Lakshmi et al., 2005). Foods rich in antioxidant have been shown to play an essential role in the prevention of cardiovascular diseases, neurogenerative diseases and inflammation.

Commonly grown oyster mushroom fungi viz., Pleurotus eous (Berk.) Sacc, Pleurotus Sajor-caju (Fr.) Singer, Pleurotus flabellatus (Berk and Br. Sacc) and Hypsizygus ulmarius (Bulliard: Fries) were used for the present study.

\section{Materials and Methods}

\section{Estimation of non-enzymatic antioxidative substances}

Mushroom extracts were assayed for nonenzymatic antioxidants such as total reduced glutathione, total phenols, vitamin A, vitamin $\mathrm{C}$, total carotenoids, lycopene and flavanoids.

\section{Estimation of total reduced glutathione (Mori et al., 1989)}

Mushroom extract $0.5 \mathrm{ml}$ was mixed with 0.5 $\mathrm{ml}$ of $5 \%$ TCA. The precipitate d protein was centrifuged down at $1000 \mathrm{rpm}$ for 10 minutes. $0.1 \mathrm{ml}$ of the supernatant was made upto 1.0 $\mathrm{ml}$ with sodium phosphate buffer. $2.0 \mathrm{ml}$ of freshly prepared DTNB were added.

The absorbance was read after $1042 \mathrm{~min}$ at $412 \mathrm{~nm}$ against a reagent blank. A set of standards were also treated in the above manner. The amount of glutathione was expressed as $\mu \mathrm{g} / \mathrm{mg}$ protein.

\section{Estimation of total phenols (Sumathi, 1998)}

Pipetted out $0.1 \mathrm{ml}$ of sample into test tubes. Made up the volume in to $3.0 \mathrm{ml}$ with distilled water. Added $0.5 \mathrm{ml}$ of FolinCiocalteau reagent. After 3 minutes added 2.0 $\mathrm{ml}$ of $20 \%$ sodium carbonate.

Mixed thoroughly, placed the tubes in boiling water bath for exactly one minute, cooled and read the absorbance at $650 \mathrm{~nm}$ against a reagent blank. A set of standards were also treated in the above manner. The amount of phenols was expressed as $\mu \mathrm{g} / \mathrm{mg}$ tissue.

\section{Estimation of vitamin A (Nield and Pearson, 1963)}

To $1.0 \mathrm{ml}$ of $10 \%$ homogenate $1.0 \mathrm{ml}$ of saponification mixture $(2 \mathrm{~N} / \mathrm{KOH}$ in alcohol) was added and heated under gentle reflux for $20 \mathrm{~min}$ at $60^{\circ} \mathrm{C}$. $25 \mathrm{ml}$ of water was added to the mixture after cooling to room temperature and the solution was transferred to a separating funnel. It was then extracted thrice with using 25,15 and $10 \mathrm{ml}$ of petroleum ether $\left(40-60^{\circ} \mathrm{C}\right)$. The ether extracts were pooled and washed with 50-100 $\mathrm{ml}$ of distilled water repeatedly until the wash water was free of alkali. The petroleum ether extract was then dried by adding anhydrous sodium sulphate. The volume of the extract was noted. $3.0 \mathrm{ml}$ of petroleum ether phase was transferred to a cuvette and read at $420 \mathrm{~nm}$ against a petroleum ether blank without delay to prevent evaporation of the solvent and destruction of carotenoids by light. Marked this reading as $\mathrm{A} 1$, the $\beta$-carotene working standards were measured at $450 \mathrm{~nm}$.

The aliquots were evaporated to dryness at $60^{\circ} \mathrm{C}$ in a water bath. The residue was taken immediately and $2.0 \mathrm{ml}$ TFA reagent were 
added to it. The mixture was rapidly transferred to a cuvette and the absorbance was measured at $620 \mathrm{~nm}$ exactly after the addition of TFA reagent. Marked this reading as A2, the vitamin A working standard was read at $620 \mathrm{~nm}$.

\section{Calculation}

For accurate calculation of the vitamin A content, it was necessary to correct for the absorbance contributed by carotene at 620 nm.

$\mathrm{A}_{3}=\mathrm{A}_{2}-\mathrm{A}_{1}$

$A_{1}=$ Absorbance of carotene at $450 \mathrm{~nm}$

$\mathrm{A}_{2}=$ Absorbance at $620 \mathrm{~nm}$ due to both carotene and vitamin $\mathrm{A}$.

$A_{3}=$ Absorbance at $620 \mathrm{~nm}$ of vitamin A.

$\mathrm{A}_{3} \times \mu \mathrm{g}$ retinol calibarator/cuvette $\mathrm{x} 3 \mathrm{x}$ total volume

Sample $=$

$\mathrm{A}_{620}$ retinol calibarator $\mathrm{x} 2 \mathrm{x}$ gram

$3=$ Volume of petroleum ether from $1.0 \mathrm{ml}$ extract

$2=$ Aliquot of the petroleum ether used for the assay

$1=10 \%$ extract taken from initial sample

The results were expressed as $\mu \mathrm{g} / \mathrm{g}$ tissue.

\section{Estimation of vitamin C (Sumathi, 1998)}

One $\mathrm{ml}$ of brominated sample extract was taken and made up the volume to $3.0 \mathrm{ml}$ by adding distilled water. Added $1.0 \mathrm{ml}$ of dinitro phenyl hydrazine reagent followed by 1 to 2 drops of thiourea into each tube. A blank was set as above but with water in place of ascorbic acid solution. Mixed the contents of the tube thoroughly and incubated at $37^{\circ} \mathrm{C}$ for 3 hours. After incubation the tubes were kept in the ice bath. Dissolved the orange red azazone crystals formed by adding $7.0 \mathrm{ml}$ of $80 \%$ sulphuric acid drop wise while the tubes were still in the water bath. The tubes in the ice bath were removed and allowed to stand for 30 minutes at room temperature and measured the absorbance at $540 \mathrm{~nm}$. The result is expressed as $\mu \mathrm{g} / \mathrm{g}$ tissue.

Estimation of total carotenoids and lycopene (Gerster, 1997)

Weighed 5 to $10 \mathrm{~g}$ of the sample. Saponified for about 30 minutes in a shaking water bath at $37^{\circ} \mathrm{C}$ after extracting the alcoholic $\mathrm{KOH}$. Transferred the saponified extract into a separating funnel (packed with glass wool and calcium carbonate) containing 10 to $15 \mathrm{ml}$ of petroleum ether and mixed gently. Taken up the carotenoid pigments into the petroleum ether layer.

Transferred the lower aqueous phase to another separating funnel and the petroleum ether extract containing the carotenoid pigments to an amber coloured bottle.

Repeated the extraction of the aqueous phase similarly with petroleum ether, until it is colourless. Discarded the aqueous. To the petroleum ether extract added a small quantity of sodium sulphate to remove turbidity. Noted the final volume of the petroleum ether extract and diluted if needed by a known dilution factor. The absorbance at $450 \mathrm{~nm}$ and $503 \mathrm{~nm}$ was noted in a spectrophotometer using petroleum ether as a blank.

\section{Calculation}

Carotenoids $(\mu \mathrm{g})=\frac{\mathrm{Px} 4 \mathrm{xVx} 100}{\mathrm{~W}}$

$\mathrm{P}=$ Optical density of the sample

$\mathrm{V}=$ Volume of the sample

$\mathrm{W}=\mathrm{Weight}$ of the sample 
$($ Lycopene $\mathrm{mg} / 100 \mathrm{~g})=$

3.1206 x OD sample $\mathrm{x}$ vol made up $\mathrm{x}$ dilution $\mathrm{x} 100$

1x weight of the sample $\mathrm{x} 1000$

\section{Estimation of flavanoids (Hertog et al., 1992)}

Added $0.5 \mathrm{ml}$ of the sample to a test tube containing $1.25 \mathrm{ml}$ of distilled water. Then added $0.075 \mathrm{ml}$ of $5 \%$ sodium nitrite solution and allowed to stand for $5 \mathrm{~min}$.

Added $0.15 \mathrm{ml}$ of $10 \%$ aluminium chloride, after 6 min $0.5 \mathrm{ml}$ of $1 \mathrm{M}$ sodium hydroxide was added and the mixture was diluted with another $0.275 \mathrm{ml}$ of distilled water.

The absorbance of the mixture at $510 \mathrm{~nm}$ was measured immediately. The flavanoid content was expressed as milligram catechin equivalents /g sample.

\section{Results and Discussion}

In oysters, non-enzymatic antioxidative substance viz., total glutathione, total phenol, flavanoids, lycopene, total carotenoids, vitamin $\mathrm{A}$ and vitamin $\mathrm{C}$ were estimated and presented in table 1. Among the oysters, $P$. eous recorded highest levels of non-enzymatic antioxidative substances. Total glutathione content was significantly very high in $P$. eous (408.37 $\mu \mathrm{m} / \mathrm{g}$ ), followed by $P$. sajor-caju $(352.45 \mu \mathrm{m} / \mathrm{g})$, P. flabellatus $(215.80 \mu \mathrm{m} / \mathrm{g})$ and $H$. ulmarius $(187.37 \mu \mathrm{m} / \mathrm{g})$. High level of total phenols (15.68 mg/g), flavanoids (7.34 $\mathrm{mg} / \mathrm{g})$, lycopene $(1.96 \mathrm{mg} / \mathrm{g})$, total carotenoid $(0.27 \mu \mathrm{g} / \mathrm{g})$ and vitamin A (5.98 $\mu \mathrm{g} / \mathrm{g})$ were recorded in $P$. eous. This was followed by $P$. sajor-caju $(13.52 \mathrm{mg} / \mathrm{g} ; 7.15$ $\mathrm{mg} / \mathrm{g} ; 1.87 \mu \mathrm{g} / \mathrm{g} ; 0.20 \mu \mathrm{g} / \mathrm{g} ; 4.52 \mu \mathrm{g} / \mathrm{g}), P$. flabellatus $(10.05 \mathrm{mg} / \mathrm{g} ; 7.05 \mathrm{mg} / \mathrm{g} ; 1.73$ $\mathrm{mg} / \mathrm{g} ; 0.19 \mathrm{mg} / \mathrm{g} ; 4.05 \mu \mathrm{g} / \mathrm{g}$ ) and H. ulmarius
$(12.72 \mathrm{mg} / \mathrm{g} ; 6.62 \mathrm{mg} / \mathrm{g} ; 1.70 \mathrm{mg} / \mathrm{g} ; 0.18 \mu \mathrm{g}$ $/ g ; 3.90 \mu \mathrm{g} / \mathrm{g})$. There was no significant difference in vitamin $\mathrm{C}$ content ( 0.41 to 0.46 $\mathrm{mg} / \mathrm{g}$ ) among the oyster mushrooms.

Foods rich in antioxidative substances have been showed to play essential role in the prevention of cardiovascular diseases (Dragsted et al., 1993), cencers (Dragsted et al., 1993), neurogenerative diseases (Joseph et al., 1999), inflammation (Joseph et al., 1999) and cutaneous ageing (Prior and Coa, 2000), The use of synthetic antioxidants has been restricted because of their possible toxic and carcinogenic effects (Gazzani et al., 1998).

The present investigations was therefore aimed to probe the natural (non-enzymatic) antioxidative substances viz., total glutathione, total phenol, flavanoids, lycopene, total carotenoids, vitamin $\mathrm{A}$ and vitamin $\mathrm{C}$, in commonly grown oyster mushrooms.

Among the oysters, $P$. eous recorded high level of natural antioxidative substances (Table 4). Total glutathione content was significantly high in $P$. eous $(408.37 \mu \mathrm{g} / \mathrm{g})$, followed by $P$. sajor-caju $(352.45 \mu \mathrm{g} / \mathrm{g}), P$. flabellatus $(215.80 \mu \mathrm{g} / \mathrm{g})$, and $H$. ulmarius $(187.37 \mu \mathrm{g} / \mathrm{g})$. High levels of total phenols (156.68 mg /g), flavanoids (7.34 mg /g), total carotenoid $(0.27 \mu \mathrm{g} / \mathrm{g})$ and Vitamin A (5.98 $\mu \mathrm{g} / \mathrm{g}$ ) were recorded in $P$. eous.

There was no significant difference in Vitamin C content (0.41-0.46 $\mu \mathrm{g} / \mathrm{g}$ ) among the oyster mushrooms (Fig.3) Murcia et al., (2002) reported that all truffles (Terfezia and Piscoa spp.) and five mushrooms (Leptista nuda, Lentinus edodes, Agrocybe cylindracea, Cantharellus lutescens and Hydrum sepundum) exihibited higher per cent of oxidative inhibition based on lipid peroxidation, deoxyribose and peroxidase. 
Table.1 Non-enzymatic antioxidative substances in oyster mushrooms

\begin{tabular}{|c|c|c|c|c|c|c|c|c|}
\hline $\begin{array}{l}\text { SL. } \\
\text { NO. }\end{array}$ & Mushroom & $\begin{array}{c}\text { Total } \\
\text { glutathione } \\
(\mu \mathrm{m} / \mathrm{g} \mathrm{DW})\end{array}$ & $\begin{array}{l}\text { Total phenol } \\
\text { (mg /g DW) }\end{array}$ & $\begin{array}{l}\text { Flavanoids } \\
(\mathrm{mg} / \mathrm{g} \mathrm{DW})\end{array}$ & $\begin{array}{c}\text { Lycopene } \\
\text { (mg/g DW) }\end{array}$ & $\begin{array}{c}\text { Total } \\
\text { Carotenoids } \\
(\mu \mathrm{g} / \mathrm{DW})\end{array}$ & $\begin{array}{r}\text { Vitamin A } \\
(\mu \mathrm{g} / \mathrm{g} D W)\end{array}$ & $\begin{array}{r}\text { Vitamin C } \\
(\mathrm{mg} / \mathrm{g} \mathrm{DW})\end{array}$ \\
\hline 1 & P. eous & $408.37^{\mathrm{a}}$ & $15.68^{\mathrm{a}}$ & $7.34^{\mathrm{a}}$ & $1.96^{\mathrm{a}}$ & $0.27^{\mathrm{a}}$ & $5.98^{\mathrm{a}}$ & $0.46^{\mathrm{a}}$ \\
\hline 2 & P. sajor-caju & $352.45^{b}$ & $13.52^{b}$ & $7.15^{b}$ & $1.87^{\mathrm{b}}$ & $0.20^{\mathrm{b}}$ & $4.52^{\mathrm{b}}$ & $0.42^{\mathrm{a}}$ \\
\hline 3 & P. flabellatus & $215.8^{c}$ & $10.05^{\mathrm{d}}$ & $7.05^{\mathrm{cb}}$ & $1.73^{c}$ & $0.19^{c}$ & $4.05^{c}$ & $0.41^{\mathrm{a}}$ \\
\hline 4 & H. ulmarius & $187.37^{\mathrm{d}}$ & $12.72^{c}$ & $6.62^{d}$ & $1.70^{\mathrm{dc}}$ & $0.18^{d}$ & $3.90^{\mathrm{d}}$ & $0.43^{\mathrm{a}}$ \\
\hline
\end{tabular}

Values are expressed as mean of 3 replicates,

Means followed by a common letter are not significantly different at $5 \%$ level by DMRT 
Methanol extract of $P$. florida have potent hydroxyl radical scavenging and lipid peroxidation inhibition (antioxidant) activities.

The antioxidant activities in Ganoderma lucidun, P. florida, P. sajor-caju, as scavenging activity was demonstrated by Lakshmi et al., (2005).

\section{References}

Ajith, T.A, Janardhanan.K.K. 2001, Antioxidant and anti-inflamatory activities of methanol extract of Phellinus rimosus (Berk.) Pilat. Indian. J. Exp. Biol. 39 (11): 1166-9.

Anon, 2000. Mushrooms. Food Digest. 23 (4): 45.

Dragsted, C.O., Strube, M. and Larsen, L.C. 1993. Cancer protective factors in fruits and vegetables. Biochemical and biological background Pharmacology and Toxicology, 72 (suppl.), 116-135.

Gazzani, G., Papetti, A., Massolini, G. and Daglia, M. 1998. Antioxidative and pro-oxidant activity of water soluble components of some common diet vegetables and the effect of thermal treatment. Journal of Food Chemistry. 6: 4118-4122.

Gerester, H., 1997. Potential role of carotene in the prevention of cardiovascular disease, International. J. Vit. Nutr. Res., 61:277291.

Hertog, M.G.L., Hollman, P.C.H and Katan, M.B. 1992. Content of potentially anticarcinogenic of 28 vegetables and 9 fruits commonly consumed in the Netherlands, J. Agric. Food Chem., 40: 2379-2383.

Joseph, J.A., Shukit-Hale, B., Denisova, N.A., et al., 1999 Reversal of Age-Related declines in neuronal signal transduction, cognitive and motor behavioral deficits with blue berry, spinach or strawberry dietary supplementation, Journal of Neuroscience, 19: 8114-8812.

Lakshmi, B., Tilak. J.C. Adhikari. S. Devasagayan. T.P.A. Janardhanan. K.K. 2005 Evaluation of antioxidant activity of selected Indian mushrooms. International J.of Pharm. Biol.42:179-185.

Madhusudhanan, K., and Chandra Mohanan. 2000. Oyster mushroom - Form Organic Waste. Kisan World. 27(7): 45-50

Mohan, and Subash Chandra Bose, 1999. Oooty 1 mushroom. Kisan World. 26(9): 55.

Mori, K., Toyomasu, T., Narba, H. and Kuroda, H. 1989. Antitumour action of fruit bodies of edible mushrooms orally administered to mice, Mushroom News Letter for Tropics. 7: 121-126.

Murcia, M.A., Martinez- Tome. M, Jimenez. A.M, Veera. A.M, Honrubia. M. Parras. P. 2002. Antioxidant activity of edible fungi (truffles and muahrooms): losses during industrial processing. J. Food. Prot. 2002. 65 (10):1614-22.

Neild, and Pearson, Butris, C.A. and Ashwood, A. 1963. Text book of Clinical Chemistry, 27: 1280-1282.

Prior, R.L., and Coa, G. 2000. Antioxidant phytochemicals in fruits and vegetables: diet and health implications. Horticulture Science, 35. 588-592.

Sumathi, S., 1998. HIV infection and antioxidant vitamin status: Report on short course on recent advances in vitaminology, $15^{\text {th }}$ June to $4^{\text {th }}$ July 1998. A.N.G.R. Agricultural University, Hyderabad.

Vijaya Khader, P., Shobadevi, G. Sarojini, J. Alakananda and Nayana Pandhya. 1999. Mushrooms for many uses. Food Digest. 22 (1):84-91.

\section{How to cite this article:}

Sudha, A., S. Srividhya, P. Geetha and Vijayakumar, M. 2017. Antioxidative Substances (Non enzymatic) in Oyster Mushrooms (Pleurotus spp.). Int.J.Curr.Microbiol.App.Sci. 6(9): 772-777. doi: https://doi.org/10.20546/ijcmas.2017.609.095 